\title{
Bcl-2 family-regulated apoptosis in health and disease
}

REVIEW

\author{
This article was published in the following Dove Press journal: \\ Cell Health and Cytoskeleton \\ 31 March 2010 \\ Number of times this article has been viewed
}

\author{
Grant Dewson \\ Ruth M Kluck \\ Molecular Genetics of Cancer \\ Division, Walter and Eliza Hall \\ Institute of Medical Research, \\ Melbourne, Australia
}

Correspondence: Ruth Kluck Molecular Genetics of Cancer Division, Walter and Eliza Hall Institute of Medical Research, IG Royal Parade, Parkville, Victoria 3052, Australia

Tel +6I 393452555

Fax +6I 393470852

Email kluck@wehi.edu.au

\begin{abstract}
Apoptotic cell death is essential for embryonic development, tissue homeostasis, and a well-functioning immune system, with aberrant apoptosis contributing to numerous disease conditions. Inadequate cell death is a major contributing factor to tumorigenesis, while excess cell death contributes to neurodegeneration and autoimmune disease. The major pathway of apoptotic cell death, the mitochondrial pathway, is controlled by the Bcl-2 family of proteins. The members of this family, more than 17 in humans, share significant sequence and structural homology, and fulfil either prosurvival or proapoptotic roles. Specific interactions between these functionally polar proteins, and their relative expression levels, govern the susceptibility of each cell to toxic insults. Here we review the current understanding on how apoptotic cell death is controlled by this important protein family. We also discuss how excessive or insufficient cell death can contribute to disease, and how targeting the Bcl-2 family offers novel therapeutic opportunities.
\end{abstract}

Keywords: apoptosis, Bcl-2, cancer, cytochrome $c$, mitochondria

\section{Bcl-2 family}

Identification of Bcl-2 (B-cell lymphoma-2) over 20 years ago as a result of its upregulation in follicular B-cell lymphoma, ${ }^{1}$ and the seminal finding that this proto-oncogene inhibits apoptosis rather than promotes proliferation, ${ }^{2}$ instigated an explosion of interest in the role of this protein, and its soon-to-be discovered relatives, in cell survival. At least 17 human Bcl-2 proteins have now been identified, each characterized by up to four regions of sequence homology, ie, the Bcl-2 homology $(\mathrm{BH})$ domains. The members are categorized into three functional groups (Figure 1). ${ }^{3}$ The first group, the prosurvival proteins, Bcl-2, Bcl- $\mathrm{x}_{\mathrm{L}}, \mathrm{Mcl}-1, \mathrm{Bcl}-\mathrm{w}, \mathrm{A} 1 / \mathrm{Bfl}-1$, and $\mathrm{Bcl}-\mathrm{B} / \mathrm{Bcl} 2 \mathrm{~L} 10$, generally contain all four $\mathrm{BH}$ domains and are responsible for protecting cells from apoptotic stimuli.

The second group comprises the BH3-only proteins, Bid, Bim, Puma, Noxa, Bad, Bmf, Hrk, and Bik, whose sequence homology with other members is restricted to the $\mathrm{BH} 3$ domain, as their name suggests. The $\mathrm{BH}$-only proteins are activated in response to diverse cellular stresses including DNA damage, growth factor deprivation, and endoplasmic reticulum stress, to initiate apoptosis. Activation of the $\mathrm{BH} 3$-only proteins may involve transcriptional upregulation, as observed for p53-dependent expression of Noxa and Puma following DNA damage. ${ }^{4}$ Alternatively, $\mathrm{BH} 3$-only proteins may be post-translationally modified. For example, while Bim and Bmf are normally sequestered by interacting with components of the cytoskeleton, following a death stimulus Bim and Bmf phosphorylation disrupts these interactions and allows interaction with other Bcl-2 
Pro-survival

\begin{tabular}{|c|c|c|c|c|c|c|}
\hline \multicolumn{6}{|c|}{ inding } & \multirow[b]{2}{*}{ TM } \\
\hline Bcl-2 & $\mathrm{BH} 4$ & & $\mathrm{BH} 3$ & $\mathrm{BH} 1$ & $\mathrm{BH} 2$ & \\
\hline $\mathrm{Bcl}-\mathrm{x}_{\mathrm{L}}$ & $\mathrm{BH} 4$ & & $\mathrm{BH} 3$ & $\mathrm{BH} 1$ & $\mathrm{BH} 2$ & TM \\
\hline Mcl-1 & $\mathrm{BH} 4$ & & $\mathrm{BH} 3$ & $\mathrm{BH} 1$ & $\mathrm{BH} 2$ & TM \\
\hline Bcl-w & & $\mathrm{BH} 4$ & $\mathrm{BH} 3$ & $\mathrm{BH} 1$ & $\mathrm{BH} 2$ & TM \\
\hline A1/Bfl-1 & & $\mathrm{BH} 4$ & & $\mathrm{BH} 1$ & $\mathrm{BH} 2$ & \\
\hline Bcl-B/Bcl2L10 & & $\mathrm{BH} 4$ & $\mathrm{BH} 3$ & $\mathrm{BH} 1$ & $\mathrm{BH} 2$ & TM \\
\hline
\end{tabular}

\section{Pro-apoptotic}
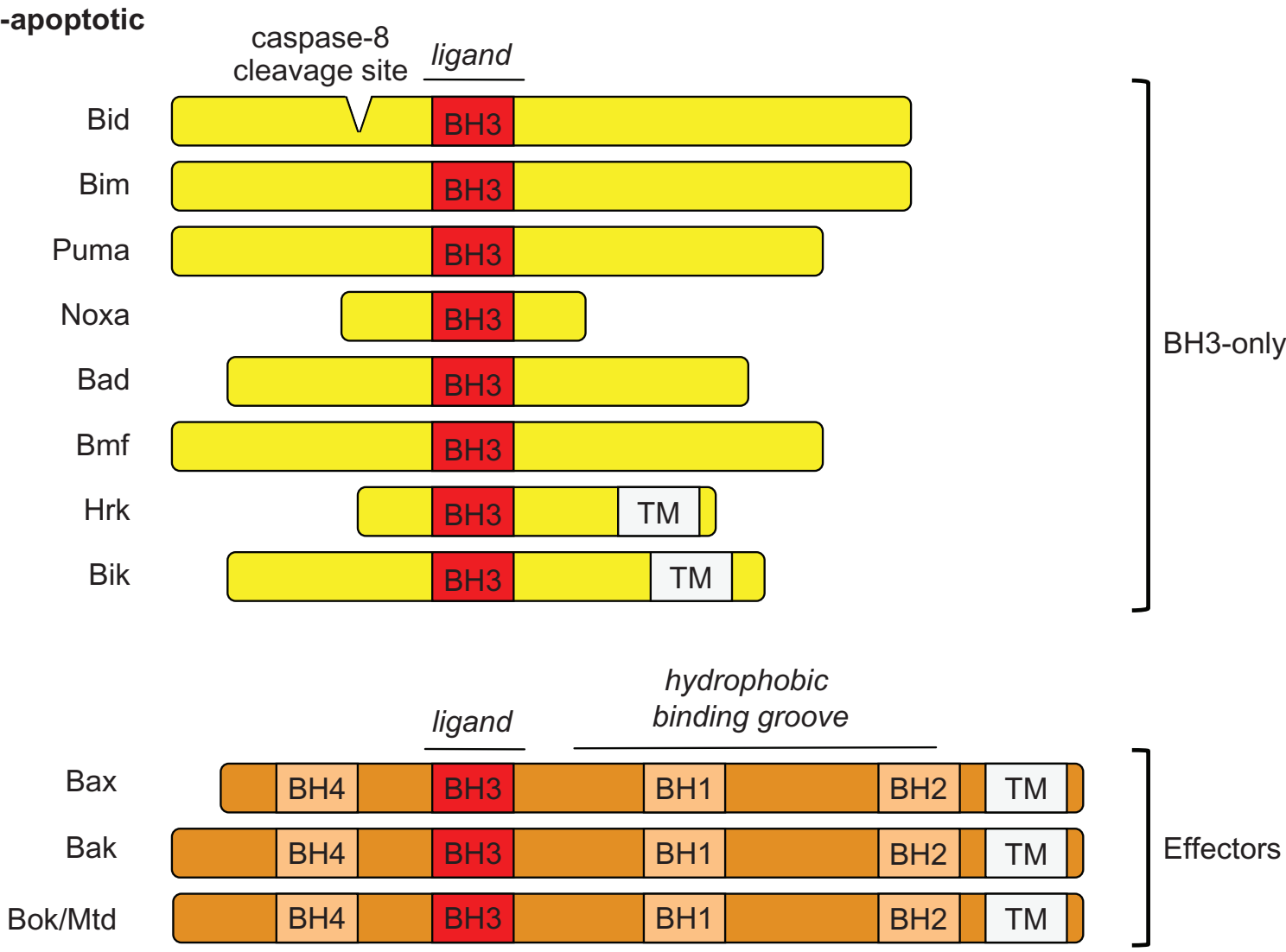

Figure I The $\mathrm{Bcl}-2$ family of apoptotic regulators.

The $\mathrm{Bcl}-2$ family of proteins are functionally categorized into three groups: i) prosurvival; ii) proapoptotic $\mathrm{BH}$-only; and iii) proapoptotic effector proteins. Protein sequences are characterized by $\mathrm{BH}\left(\mathrm{Bcl}-2\right.$ homology) domains I-4. Note that while the $\mathrm{BH} 4$ domain as initially defined ${ }^{138}$ is absent in Bak, $\mathrm{Bax}$, Mcl-I, and $\mathrm{Al}$, the $\mathrm{BH} 4$ domain described more recently $y^{73}$ appears to be present in most multidomain proteins. The indicated $\mathrm{BH} 3$ ligand and hydrophobic binding groove regions mediate homo- and heterotypic "BH3:groove" interactions between family members. Many Bcl-2 members also have a C-terminal transmembrane (TM) domain. Note also that Bok/Mtd is included as an effector protein based on sequence homology to Bak and Bax, but a similar proapoptotic function is yet to be verified.

family members to initiate apoptosis. ${ }^{5,6}$ Another activation mechanism is the cleavage of Bid by caspase- 8 to generate the activated truncated form, tBid.

The third group, Bax, Bak, and Bok/Mtd, are again multidomain proteins, and contain all four BH domains as do the prosurvival proteins, but they are proapoptotic, with their activation downstream of BH3-only proteins ultimately responsible for the demise of the cell. Bak and Bax activation and function are discussed below.

Recently, novel putative members of the Bcl-2 family have been identified with differing degrees of sequence homology. For example, Bcl2L12, ${ }^{7} \mathrm{Bfk},{ }^{8}$ and Bcl-G/Bcl2L14 ${ }^{9}$ all contain 
BH domains 2 and 3 only. However, whereas Bcl2L12 is a prosurvival protein, Bfk and Bcl-G are proapoptotic. ${ }^{8-10}$ Further, Bcl-Rambo/Bcl2L13 is a multidomain proapoptotic protein containing $\mathrm{BH}$ domains $1-4$, seemingly homologous to Bak and Bax. ${ }^{11}$ However, in contrast with Bak and Bax, the proapoptotic potential of Bcl-Rambo is independent of its $\mathrm{BH}$ domains. ${ }^{11}$ Therefore, there is currently considerable interest in identifying novel Bcl-2 homologs and elucidating their precise roles in regulating apoptosis.

It is clear that multiple and specific interactions between the three groups of $\mathrm{Bcl}-2$ proteins coordinate the apoptotic response. Considerable effort has been made to decipher these interactions, and so understand the susceptibility of each cell to apoptotic stimuli.

\section{Prosurvival Bcl-2 proteins: Guardians at the mitochondrial gate}

A number of mechanisms were initially proposed for how Bcl-2 and its prosurvival relatives protect cells from stress. Originally it was argued that Bcl-2 acted as a free-radical scavenger and suppressed the effect of damaging reactive oxygen species generated by mitochondrial respiration. ${ }^{12}$ Consistent with this, mice deficient for Bcl-2 developed polycystic kidney disease and cerebellar neuron loss, ${ }^{13}$ which can be attributed to oxidative stress. Further, Bcl-2 expression could protect cells from oxidant-induced death. ${ }^{12}$ Subsequently, Bcl-2 was proposed to block the "permeability transition pore" in the mitochondrial inner membrane, and so indirectly block the associated production of oxygen species. However, studies have since questioned the importance of the antioxidant effects of Bcl-2 for its prosurvival function, ${ }^{14}$ and the role of the permeability transition pore in apoptosis, ${ }^{15}$ suggesting that Bcl-2 protects cells from apoptosis principally via other mechanisms.

The early evidence that $\mathrm{Bcl}-2$ protected from oxidative stress provided the first hint that Bcl-2 function was associated with mitochondrial function. ${ }^{12}$ Then in 1994, Newmeyer et al reported that mitochondria were necessary for apoptotic changes in a cell-free system, and that Bcl-2 could block the effect of mitochondria. ${ }^{16}$ That group and the Wang group then showed that Bcl-2 actually acts by preserving the integrity of the mitochondrial outer membrane. ${ }^{17,18}$ Maintaining mitochondrial integrity serves not only to conserve mitochondria as the powerhouses of the cell, but also to prevent proapoptotic proteins such as cytochrome $c$ and Smac/DIABLO from being released into the cytoplasm where they rapidly activate a family of proteases, the caspases (Figure 2). ${ }^{19-21}$ Once activated, caspases cleave a plethora of intracellular proteins to package the cell in readiness for its "silent" noninflammatory removal by resident phagocytes.

While the Bcl-2 family regulates the mitochondrial or "intrinsic" apoptotic pathway, it does not regulate the death receptor or "extrinsic" pathway, at least in most cell types. In the death receptor pathway, apoptotic signalling is initiated by ligation of cell surface receptors for Fas (CD95/ Apo-1) ligand, tumor necrosis factor (TNF)- $\alpha$, and TRAIL (TNF-related apoptosis-inducing ligand). This activates caspase-8, which in turn directly activates downstream caspases, without the need for mitochondria or the Bcl-2 proteins. ${ }^{14}$ However, in certain cells (termed Type II cells), including hepatocytes and pancreatic $\beta$-cells the death receptor pathway does recruit mitochondria and the Bcl-2 family via caspase- 8 cleavage of the $\mathrm{BH} 3$-only protein Bid to generate tBid (Figure 2). ${ }^{22-24}$ Consequently, the Bcl-2 family also plays a role in immune-mediated conditions such as diabetes (see below).

Given that Bcl-2 proteins control apoptosis by regulating permeabilization of the mitochondrial outer membrane, it is not surprising that several members locate to this membrane. They do so via a hydrophobic C-terminal transmembrane (TM) domain that targets them principally to mitochondria. An association with the mitochondrial outer membrane is not always constitutive, because certain $\mathrm{Bcl}-2$ proteins require apoptotic signalling to drive them there. For example, Bax is actually cytosolic in the majority of healthy cells, but translocates to the mitochondrial outer membrane during cell death. ${ }^{25}$ This contrasts with its structural and functional homolog, Bak, which is resident at mitochondria before a death stimulus. $\mathrm{BH} 3$-only and prosurvival proteins are also often distributed between the cytosol and mitochondria in healthy cells, with at least some members (Bim, Bcl- $x_{L}$ and $\mathrm{Bcl}-\mathrm{w})$ reported to translocate to membranes during apoptosis. ${ }^{5,26,27}$ Bcl-2, Bak, and Bax have also been detected at the endoplasmic reticulum membrane, although a proposed role in regulating $\mathrm{Ca}^{2+}$ homeostasis in the endoplasmic reticulum is contentious. ${ }^{28-31}$

\section{Interactions between $\mathrm{Bcl}-2$ members determine cell fate}

In response to an apoptotic stimulus, the balance of prosurvival and proapoptotic Bcl-2 proteins, and the specific interactions between them, determine the proapoptotic activity of Bak and Bax. ${ }^{32-34}$ Activation of Bak and Bax 


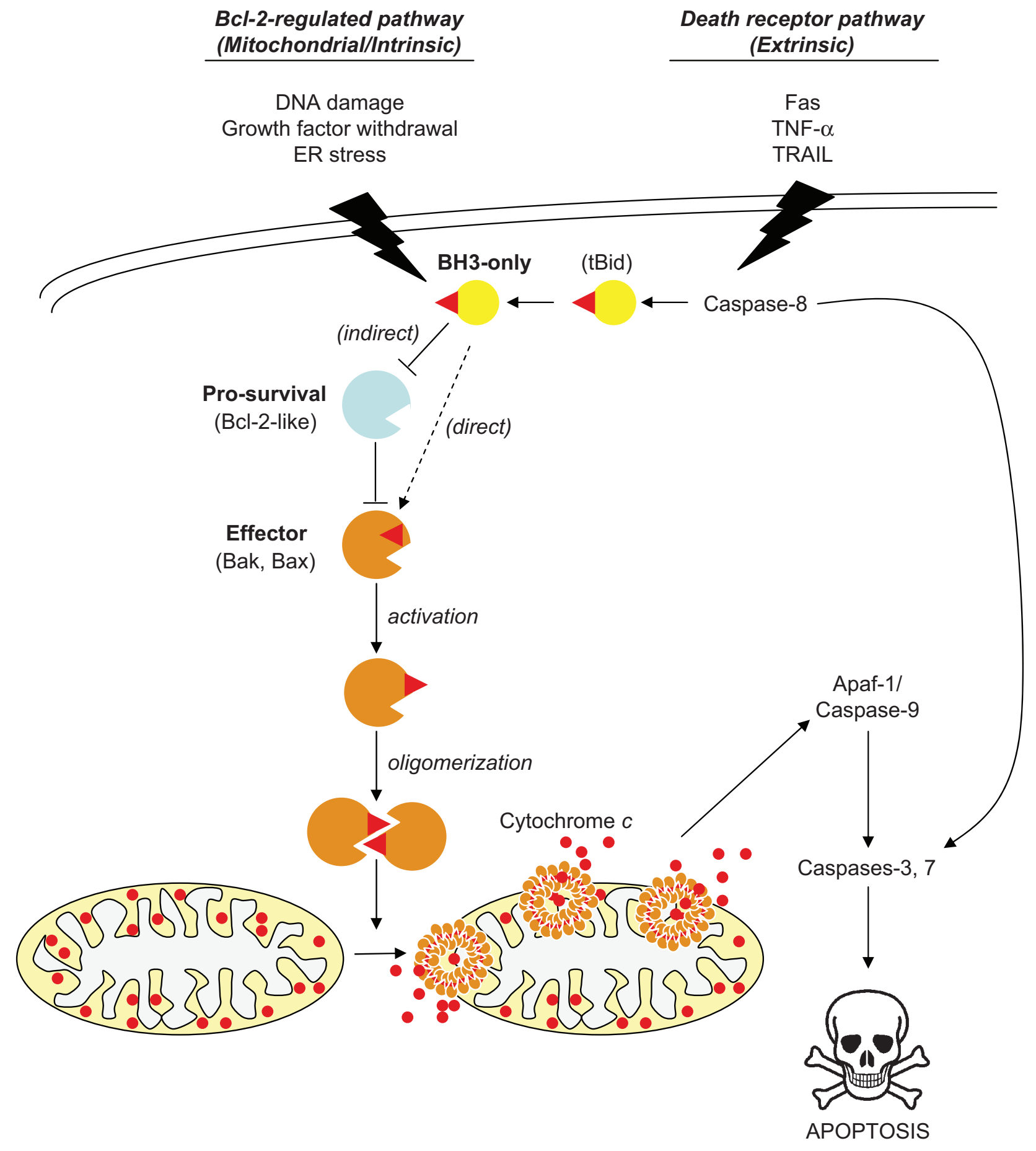

Figure 2 The pathways to apoptotic cell death.

In the Bcl-2-regulated pathway (also called the mitochondrial or intrinsic pathway) of apoptosis, a range of stimuli triggers the activation of BH3-only proteins, which then bind via $\mathrm{BH} 3$ :groove interactions to specific prosurvival proteins. Certain $\mathrm{BH} 3$-only proteins (eg, $\mathrm{BBid}$ and $\mathrm{Bim}$ ) may also directly bind and activate the effector $\mathrm{Bcl}-2$ proteins $\mathrm{Bak}$ and $\mathrm{Bax}$ (broken arrow) to expose their BH3 domain (red triangle). If prosurvival proteins are occupied by BH3-only proteins, activated Bak and Bax are free to homo-oligomerize via a BH3:groove interaction. The Bak and Bax oligomers then form pores that permeabilize the mitochondrial outer membrane leading to the release of several proapoptotic proteins including cytochrome $c$. Once in the cytosol, cytochrome $c$ binds to the adaptor protein Apaf-I to activate the downstream caspases that cleave multiple cellular proteins during apoptosis. In the death receptor pathway (also called extrinsic pathway), the Fas, TNF- $\alpha$, and TRAIL ligands bind to their cell surface receptors to activate caspase-8. Activated caspase-8 then directly activates the downstream caspases, which in most cells is sufficient to cause cell death. However, certain cells (Type II cells) also require caspase-8 to cleave $\mathrm{Bid}(\mathrm{tBid})$, which recruits the mitochondrial arsenal of proapoptotic proteins to fully activate the downstream caspases. 
involves major conformation change and self-association into large oligomers that permeabilize the mitochondrial outer membrane, potentially by forming a proteinaceous pore, thereby killing the cell (Figure 2). ${ }^{35}$ Thus, the $\mathrm{BH} 3$-only proteins are charged with instigating Bak and Bax homo-oligomerization, whilst the prosurvival $\mathrm{Bcl}-2$ proteins are charged with preventing it.

How BH3-only proteins initiate Bak and Bax activation is debated, but is proposed to be by two seemingly distinct mechanisms, ie, the "direct" and "indirect" models of Bak and Bax activation. ${ }^{36,37}$ Briefly, the direct model posits that a subclass of the BH3-only proteins, termed "activators" (Bim, tBid, and Puma), bind directly to Bak and Bax to cause their activation. The role of prosurvival proteins in this model is to sequester the "activators". The role of other BH3-only proteins, termed "sensitizers" (for example, Noxa and Bad) is to bind to prosurvival proteins and displace the "activators". ${ }^{38}$ Concerns with this model include the difficulty in detecting binding of activator $\mathrm{BH} 3$-only proteins to Bak and Bax, although this interaction may only be transient. In addition, if direct activators are required for Bak and Bax activation, removing these direct activators should have the same effect as removing both Bak and Bax, ie, complete insensitivity to the majority of cell death stimuli. ${ }^{39}$ However, this is not the case in genetically altered mice and cells. ${ }^{40}$

The indirect model argues that activation of Bak and Bax does not require this interaction with $\mathrm{BH} 3$-only proteins. Rather, Bak and Bax are initially in a "primed" form and sequestered by prosurvival proteins. Then, in response to apoptotic stimuli, activated $\mathrm{BH} 3$-only proteins bind to prosurvival proteins, displacing "primed" Bak and Bax. ${ }^{40,41}$ The displaced Bak and Bax may then autoactivate the inactive pool and together permeabilize the mitochondrial outer membrane. ${ }^{42}$ In the indirect model, however, the initial activating stimulus responsible for "priming" Bak and Bax has not been defined, and only minor levels of Bak and Bax appear bound to prosurvival proteins in healthy cells. ${ }^{37,43}$ Irrespective of the exact means by which Bak and Bax become activated, it is clear that the balance of prosurvival (Bcl-2-like) and proapoptotic (BH3-only and effector) proteins is the key to this activation, and thus in governing susceptibility of a cell to toxic insult.

\section{Structure of $\mathrm{Bcl}-2$ proteins $\mathrm{Bcl}$-2-like fold}

The molecular basis of the interactions between the Bcl-2 proteins centers around the ubiquitous BH3 domain (Figure 1) and its ability to bind to a hydrophobic surface groove in the multidomain proteins (Figures 1 and 3). Significant insight into these "BH3: groove" interactions has been gained from the molecular structures of the Bcl-2 proteins, in particular of $\mathrm{BH} 3$-only ligands bound to the groove of prosurvival proteins (Figure 3). Nuclear magnetic resonance or x-ray structures of most prosurvival proteins are now available either as monomers (including $\mathrm{Bcl}-\mathrm{x}_{\mathrm{L}},{ }^{44} \mathrm{Bcl}-2,{ }^{45} \mathrm{Mcl}-1,{ }^{46}$ $\mathrm{Bcl}-\mathrm{w},{ }^{47}$ and $\mathrm{A} 1^{48}$ ) or complexed with $\mathrm{BH} 3$ peptides derived from other Bcl-2 members (Figure 3A). ${ }^{49-51}$

Structures of nonactivated $\mathrm{Bax}^{52}$ and $\mathrm{Bak}^{53}$ are now also available and, despite their proapoptotic function, exhibit a similar overall fold to that of the prosurvival proteins (Figure 3B). Thus, all multidomain members (prosurvival proteins as well as Bax and Bak) are globular proteins consisting of two core hydrophobic $\alpha$-helices shrouded by six or seven amphipathic $\alpha$-helices. ${ }^{54}$ The hydrophobic C-terminal TM domain (Figure 1), responsible for targeting the multidomain homologs to intracellular membranes, is missing from most of the structures (except cytosolic Bax, Figure 3C). Thus, the structure of the TM of most members is not known, nor how the TM orientates each protein at the membrane surface.

In contrast with the multidomain members, the $\mathrm{BH} 3$-only proteins appear intrinsically unstructured, perhaps to allow the $\mathrm{BH} 3$ domain to adopt the optimal helical structure upon binding to a hydrophobic groove and so improve binding affinity. ${ }^{55} \mathrm{Bid}$ is an exception, because its structure is similar to that of the multidomain proteins (ie, a Bcl-2-like fold) despite the absence of $\mathrm{BH}$ domains 1,2 , and 4. ${ }^{56,57}$ However, upon apoptotic signaling and cleavage by caspase- 8 to tBid, it also becomes less structured, which may facilitate binding to a hydrophobic groove. ${ }^{58}$

\section{BH3:groove interactions}

The distinct hydrophobic groove on the surface of all prosurvival proteins, has been shown by biochemical and structural studies to be the docking site for the $\mathrm{BH} 3$ domains of proapoptotic BH3-only proteins (Figure 3A), and potentially also the $\mathrm{BH} 3$ domains of the activated or "primed" forms of Bak and Bax. ${ }^{46,50,51}$ The hydrophobic groove is not a promiscuous receptor for all $\mathrm{BH} 3$ domains, because prosurvival protein binding of $\mathrm{BH} 3$ ligands is highly selective. ${ }^{59}$ For example Mcl-1 and A1 bind Noxa avidly, but do not bind Bad. Conversely, Bcl-2, Bcl- $\mathrm{x}_{\mathrm{L}}$, and Bcl-w bind $\mathrm{Bad}$, but not Noxa. However, all prosurvival proteins bind Bim and Puma with high affinity. As a result, these specific BH3:groove interactions provide an exquisitely regulated mechanism by which prosurvival proteins sequester their proapoptotic relatives and so block apoptosis. 
A
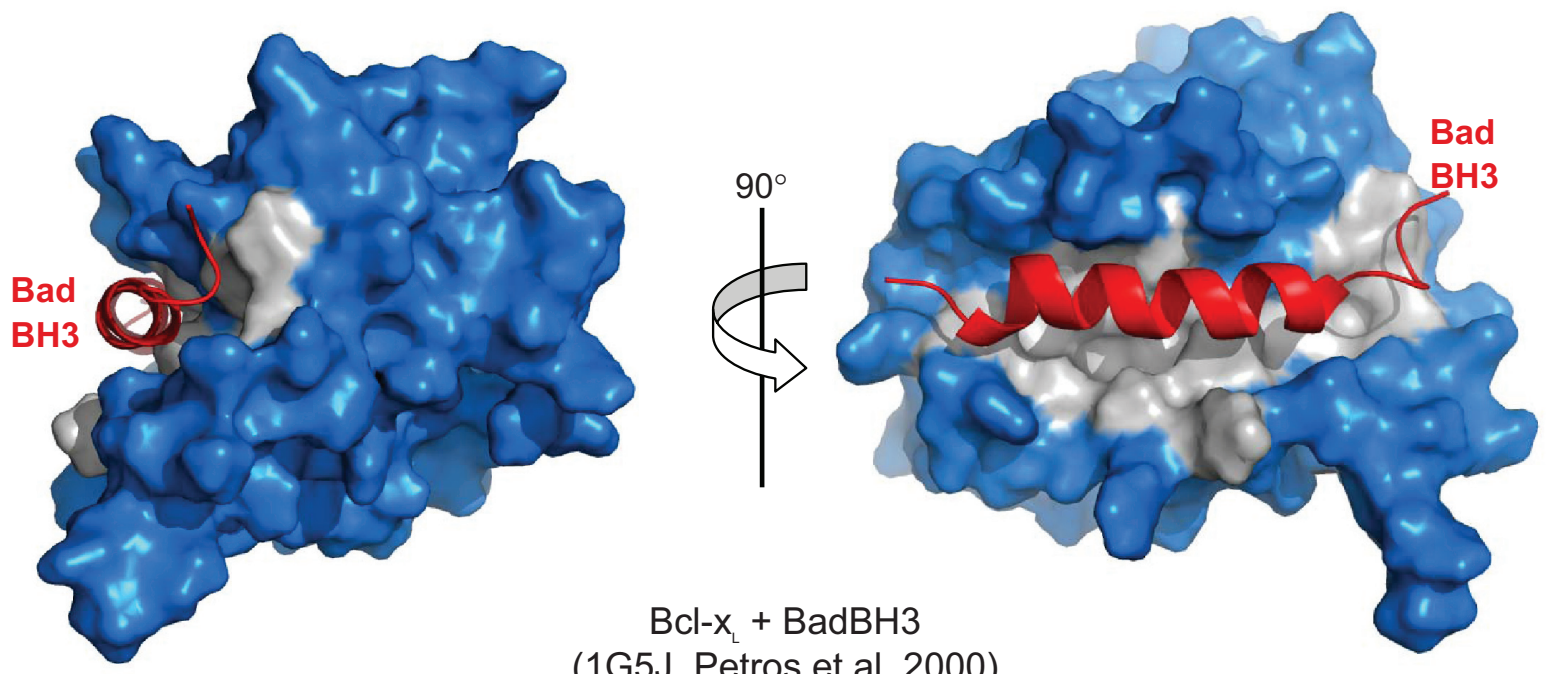

(1G5J, Petros et al, 2000)

B

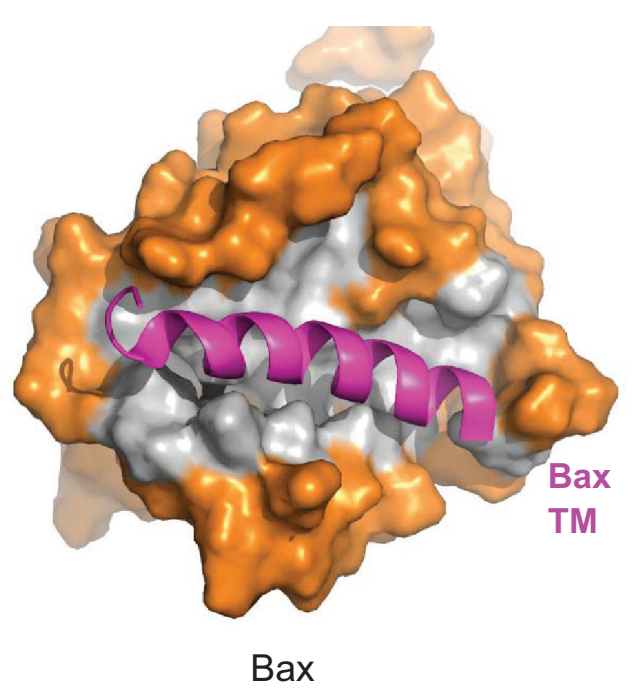

(1F16, Suzuki et al, 2000)
C

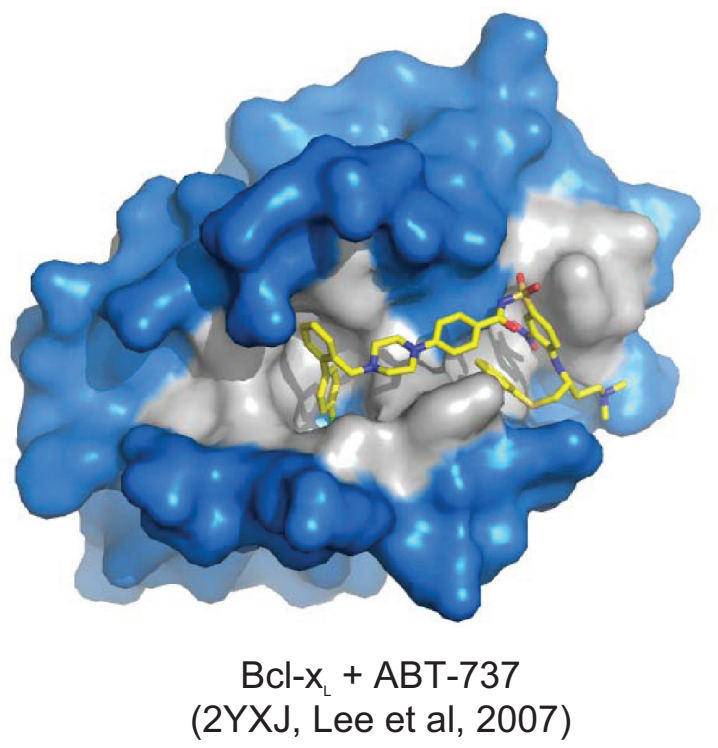

Figure 3 Structural evidence that the hydrophobic surface groove of $\mathrm{Bcl}-2$ proteins can bind $\mathrm{BH} 3$ ligands and transmembrane domains.

A) Structural representation of $\mathrm{Bcl}-\mathrm{x}_{\mathrm{L}}$ complexed with a peptide derived from the $\mathrm{Bad} \mathrm{BH} 3$ domain. The fold of $\mathrm{Bcl}-\mathrm{x}_{\mathrm{L}}$ (and other prosurvival $\mathrm{Bcl}-2$ proteins) $\mathrm{creates}$ a hydrophobic surface groove (grey) that acts as a receptor for the $\mathrm{BH} 3$ domain of Bad (red helix) and other proapoptotic proteins. ${ }^{51}$ B) The Bax hydrophobic groove is occupied by its TM domain. The structure of cytosolic nonactivated Bax displays a similar fold to that of its prosurvival relatives, including a hydrophobic surface groove (grey). Binding of the Bax transmembrane domain (pink) to that groove facilitates the cytosolic locale of Bax prior to apoptosis. ${ }^{52} \mathbf{C}$ ) $\mathrm{A} \mathrm{BH} 3$ mimetic also binds to the prosurvival hydrophobic groove. The structure of a small molecule mimetic of Bad,ABT-737 (yellow), bound to the hydrophobic groove of Bcl- $\mathrm{x}_{L}$ (grey) is analogous to that observed for the Bad BH3 peptide bound to Bcl- $x_{L}$ shown in A. ${ }^{97}$ Images were generated in Pymol using the indicated RCSB Protein Data Bank files (IG5J, IFI6, 2YXJ).

Both Bak and Bax have a hydrophobic surface groove, indicating it may also be an important interaction site for the proapoptotic members. Indeed, while the structures of activated Bak and Bax are not yet available, our recent biochemical studies show that a $\mathrm{BH} 3$ :groove interface forms between two activated Bak or Bax molecules (GD and RK, unpublished data). ${ }^{60}$ That is, the Bak and Bax activation process involves exposure of their BH3 domain, with this domain then able to bind to the groove in another molecule to form homodimers. This BH3:groove interaction is required to kill the cell. ${ }^{60,61}$

There is now structural information regarding binding of BH3-only ligands to Bax. As mentioned above, this 
type of interaction may initiate activation and conformation change of Bak and Bax as proposed by the "direct" activation model. One might speculate that such an interaction would occur via a BH3:groove interaction, based on the interactions between other members. However, this was not the case because the Bim $\mathrm{BH} 3$ peptide bound to a site distinct from the Bax groove. ${ }^{62}$ Nevertheless, very recent mutagenesis studies indicate that interaction at this alternative site might precede a necessary $\mathrm{BH} 3$ :groove interaction. ${ }^{63}$ Hence, it remains possible that $\mathrm{BH} 3$ :groove interactions underlie all binding between Bcl-2 family members, as we have speculated. ${ }^{37}$ Clearly, further studies, including structures of full-length $\mathrm{BH} 3$-only proteins bound to Bak and Bax, preferably as the membrane-bound forms, are needed to clarify this important step in apoptotic cell death.

\section{TM:groove interactions}

While the TM domain is absent in most structures of $\mathrm{Bcl}-2$ proteins, the Bax structure is of the full-length protein and shows the hydrophobic TM sequestered within its hydrophobic groove (Figure 3B). ${ }^{47,52}$ The structure of Bcl-w also shows a $\mathrm{C}$-terminal helix bound to the hydrophobic groove, although a more $\mathrm{C}$-terminal hydrophobic region (probable TM) had been truncated. In Bax, the TM:groove conformation supports its cytosolic localization in healthy cells. In response to an apoptotic stimulus, Bax (and Bcl-w) translocates to mitochondria with the TM moving from the groove to insert across the mitochondrial outer membrane. ${ }^{26,34}$ Therefore, the hydrophobic groove not only governs interactions between Bcl-2 family members, but may also govern subcellular distribution of these proteins.

\section{Conformation change during apoptosis}

Given that biochemical studies suggest that both proapoptotic and prosurvival proteins undergo major conformation changes during apoptosis, most of the structures currently available may only reflect the conformation prior to apoptosis. Furthermore, biochemical evidence suggests that some Bcl-2 proteins adopt markedly different conformations once associated with the lipid environment of the mitochondrial outer membrane. Bak and Bax conformation change during apoptosis includes exposure of $\mathrm{N}$-terminal epitopes and the $\mathrm{BH} 3$ domain (the binding motif) on their way to adopting their "activated" conformation. ${ }^{34,60,61,64}$ In addition, Bax inserts two hydrophobic regions ( $\alpha$-helices 5 and 6) into the membrane to adopt a multispanning membrane topology. ${ }^{65,66}$ The enhanced membrane integration of Bax may perturb the mitochondrial outer membrane analogous to the mechanism by which pore-forming bacterial toxins porate a lipid bilayer. ${ }^{67}$ Intriguingly, Bcl-2 has also been shown to insert $\alpha$-helices 5 and 6 into the mitochondrial outer membrane, ${ }^{46}$ with this multispanning conformer of Bcl-2 acting as a dominant-negative form of Bax by binding to the multispanning Bax conformer and preventing its oligomerization into large complexes. ${ }^{68}$ Elegant nuclear magnetic resonance studies of $\mathrm{Bcl}-2$ proteins in lipid membrane environments also suggest that both prosurvival and proapoptotic proteins insert their hydrophobic core helices into membranes. ${ }^{69-72}$

In summary, biochemical and structural analyses are starting to paint a picture of the postapoptotic, membrane-integrated forms of the Bcl-2 proteins. However, molecular structures of the activated and oligomerized conformers of Bak and Bax are still eagerly anticipated, along with their undoubted insight as to how these crucial proteins damage mitochondria.

\section{A non-apoptotic role for $\mathrm{Bcl}-2$ proteins}

Despite limited amino acid sequence homology, a number of viral Bcl-2 homologues adopt a remarkably similar protein structure to $\mathrm{Bcl}-2$ (eg, F1L, ${ }^{73} \mathrm{M} 11 \mathrm{~L},{ }^{74}$ and $\mathrm{BHRF} 1{ }^{75}$ ). Moreover, several of these function as orthologs of prosurvival proteins in that they bind $\mathrm{BH} 3$-only proteins or Bak and Bax to block apoptosis and so sustain the viral infection. ${ }^{76,77}$ Thus, one might speculate that attenuated viruses could be used therapeutically to block apoptosis, and that compounds that target Bcl-2 proteins could be used to counter pathogenic infections. It is also interesting to note that two vaccinia virus proteins that adopt a Bcl-2-like fold were recently shown to inhibit NF- $\mathrm{kb}$ activation, and so prevent the inflammatory response against the virus. ${ }^{78}$ This raises the intriguing possibility that mammalian Bcl-2-like proteins may have a function distinct from their role in apoptosis.

\section{Bcl-2-regulated apoptosis important in development}

The critical role of $\mathrm{Bcl}-2$ and its relatives in development and tissue homeostasis is apparent from mice in which one or both copies of the relevant gene have been deleted. Mice lacking both copies of the Bcl-2 gene $\left(b c l-2^{-/-}\right)$die in utero. ${ }^{13}$ These $b c l-x_{\mathrm{L}}{ }^{-/-}$mice die in utero because of defects in the development of the hematopoietic system..$^{79}$ Deletion 
of Mcl-1 resulted in failure of the early embryo to implant. However, conditional deletion of Mcl-1 in T- and B-cells indicated that this gene is critical for the development and maintenance of a functioning immune system. ${ }^{80}$ These studies highlight the importance of the prosurvival proteins in maintaining cell survival during development.

Certain cells are destined to die during development to allow tissue remodelling. Thus, deleting proapoptotic genes also results in developmental abnormalities, most marked in the central nervous system. For example, neurodevelopmental defects develop in caspase-9 ${ }^{81,82}$ and apaf- $1^{83}$ knock-out mice, and in mice expressing a mutant of cytochrome $c$ that can not activate caspases. ${ }^{84}$ In terms of the Bcl-2 family, mice that lack both Bak and Bax die perinatally because of severe craniofacial and neuronal developmental defects. ${ }^{85}$ It is also noteworthy that mice deficient in either Bak or Bax have relatively few abnormalities, ${ }^{85,86}$ indicating that either Bak or Bax is generally able to mediate apoptosis. These studies highlight both the importance of apoptosis in the developing embryo, and the need for either Bak or Bax for apoptosis.

With at least eight $\mathrm{BH} 3$-only proteins in mammals, deletion of any one $\mathrm{BH} 3$-only protein has less profound effects on development, consistent with a degree of redundancy in their roles as sensors of intracellular stress. The exception is Bim, which is particularly important for development, because a significant proportion (approximately 40\%) of $\mathrm{bim}^{-/-}$mice die in utero, and those that survive are plagued by expansion of both lymphoid and myeloid compartments and by the development of autoimmune disease. ${ }^{87}$ In summary, the Bcl-2 proteins play a critical role during development, both in protecting cells from the rigors of division and differentiation and in removing cells to allow tissue remodelling.

\section{Dysregulated apoptosis contributes to multiple diseases}

As well as a pivotal role during development, Bcl-2 proteins are essential for homeostasis in mature tissues, such that defects in expression levels or activation status contribute to a range of pathologies. Before the discovery of Bcl-2, the original description of apoptosis as a programmed form of cell death distinct from necrosis also reported a major role for this cell death in both physiologic and pathologic conditions. ${ }^{88}$ Pathologies included those in which apoptosis is blocked, eg, in cancer, and those in which apoptosis is excessive or inappropriate, eg, in neurodegeneration, autoimmunity, and ischemia. Now, with our increasing understanding of how the $\mathrm{Bcl}-2$ proteins regulate apoptosis, we have the exciting opportunity to target Bcl-2-regulated apoptosis for therapeutic benefit.

\section{Cancer}

Inhibition of apoptosis is a hallmark of tumorigenesis, at least in part because cells with DNA damage fail to be deleted. ${ }^{89}$ The first example was the finding of Bcl-2 upregulation due to $\mathrm{t}(14: 18)$ chromosomal translocation in follicular B-cell lymphoma. Since then, over-expressed Bcl-2 has been implicated in a number of other cancers, including chronic lymphocytic leukemia, acute lymphoblastic leukemia, small cell lung cancer, prostate cancer and nonHodgkin's lymphoma. Causes of Bcl-2 overexpression include chromosomal translocation, DNA hypermethylation, and downregulation of the microRNAs that target Bcl-2. Mcl-1 overexpression is also associated with hematopoietic malignancies, such as multiple myeloma and chronic myeloid leukemia, and with solid tumors, such as pancreatic cancer and melanoma. High levels of prosurvival proteins are often associated with aggressive malignancies and with resistance to chemotherapy. In mice, overexpression of prosurvival Bcl-2 proteins alone does not efficiently drive tumorigenesis, but it does synergize with other oncogenic transformations such as overexpression of myc or mutations in $\mathrm{p} 53 .{ }^{90}$

Although either Bak or Bax is necessary for apoptosis, compared with overexpression of the prosurvival proteins, relatively few cancers are associated with Bak or Bax downregulation or loss-of-function mutations. This is presumably because of the expression of both Bak and Bax in most cells, and their functional overlap. For instance, failure to undergo apoptosis would require loss of, or mutation in, both alleles of Bak and both alleles of Bax. Even so, low levels of Bak or Bax, or perhaps more pertinently a low ratio of proapoptotic protein to prosurvival protein, can correlate with increased incidence, poor prognosis, or resistance to chemotherapy in certain cases of colorectal cancer, melanoma, and chronic lymphocytic leukemia. ${ }^{91-94}$

Recently developed therapeutics that specifically target the Bcl-2 protein family have considerable potential for the treatment of neoplastic disorders. ${ }^{95}$ For example, Abbott Laboratories used a structure-based approach to design small molecules that can enter cells and mimic BH3-only proteins in their ability to bind to the prosurvival Bcl-2 proteins. The first of these BH3-mimetics, ABT-737, mimics Bad because it binds with high affinity to $\mathrm{Bcl}-\mathrm{x}_{\mathrm{L}}, \mathrm{Bcl}-2$, and Bcl-w, but not to Mcl-1 or A1 (Figure 3C), ${ }^{96,97}$ and can specifically kill cancer cells whose survival is reliant upon the targeted prosurvival proteins. ${ }^{96,98}$ ABT-737, and its orally 
available analog ABT-263, have shown considerable promise in preclinical studies in mice, either as a single agent or in combination with common therapeutics. ${ }^{99-102}$ ABT-263 is currently in Phase I clinical trials for the treatment of hematologic malignancies including chronic lymphocytic leukemia, acute lymphoblastic leukemia, and multiple myeloma.

\section{Neurodegeneration}

Mature neurons are exquisitely sensitive to stress such as hypoxia and, because they are not readily replaced, protecting these cells is crucial to stave off cell loss and neural deficits. Prosurvival proteins are important for this protection. For example, in mice lacking Bcl-2 the nervous system develops essentially normally, but there is a progressive loss of peripheral neurons after birth. ${ }^{103}$ In addition, overexpression of Bcl-2 in neurons was found to protect from neuronal loss and limit infarct size in a mouse model of cerebral ischemia. ${ }^{104}$ The Bcl-2 family is also implicated in chronic neurodegenerative conditions, because Bax inhibition prevented neuronal death in a mouse model of Parkinson's disease. ${ }^{105}$ Together these findings highlight the importance of the Bcl-2 family and apoptosis in regulating neuronal cell survival following both acute and chronic injury, and suggest that targeting Bcl-2-regulated apoptosis may provide a valuable therapy for neuronal injury and a range of neurodegenerative diseases. ${ }^{106,107}$ Clearly, chronic inhibition of apoptosis as a means to prevent neurodegeneration may have the complication of encouraging tumors. However, short-term inhibition of apoptosis, for example immediately following ischemia, may afford sufficient protection from the initial hypoxic insult to ensure long-term neuronal cell survival.

\section{Cardiovascular disease}

Terminally differentiated cardiac myocytes are not replaced once lost. Depletion of the myocardium as a result of apoptosis contributes to a number of cardiovascular disorders, and, as in the nervous system, the Bcl-2 family is central in both causing and preventing this loss. ${ }^{108}$ An imbalance in the ratio of prosurvival to proapoptotic $\mathrm{Bcl}-2$ proteins appears causal in cardiovascular disease, including ischemic heart disease. In addition, Bcl-2 overexpression in mice protected against ischemia-reperfusion injury of cardiac myocytes, and blocked apoptosis of these cells in culture. ${ }^{109,110} \mathrm{Bcl}-2$ may also protect the heart from subthreshold injury given that acute ischemiareperfusion preconditioning in mice was shown to inhibit myocyte apoptosis by a mechanism involving upregulation of
Bcl-2. ${ }^{111}$ Cardiac damage seems to hold a central role for Bax, because cardiac myocyte apoptosis and consequent infarct size was markedly reduced in $b a x^{-/-}$mice. ${ }^{112}$ Therefore, preventing loss of cardiac cells by inhibiting apoptosis may have significant therapeutic potential in the treatment of various cardiovascular disorders. ${ }^{108,113}$

\section{Asthma}

Asthma is characterized by infiltration of eosinophils into the airways resulting in bronchial hyperresponsiveness. The accumulation and persistence of these granulocytes in the asthmatic lung results from several factors, including selective adhesion and migration, and also prolonged survival conferred by proinflammatory growth factors such as interleukin-5, interleukin-3, and granulocyte macrophage colony-stimulating factor. ${ }^{114,115}$ Consistent with this, in a mouse model of asthma, prolonging eosinophil survival increased disease severity, and shortening survival decreased the severity. ${ }^{116}$ These changes in eosinophil survival appear linked to the Bcl-2 protein family, because cytokinedriven eosinophil survival involves Bcl-2 upregulation and inhibition of Bax. ${ }^{117,118}$ Furthermore, increased Bcl-2 expression in sputum eosinophils is correlated with increased severity of childhood and acute asthma. ${ }^{119,120}$

Steroid therapies, commonly used in the treatment of asthma, induce apoptosis and clearance of airway eosinophils. ${ }^{115,121}$ Furthermore, in clinical and preclinical studies cytokine-receptor antagonists and cyclin-dependent kinase (CDK) inhibitors helped resolve airway inflammation in asthma at least partly by inducing apoptosis of airway eosinophils. ${ }^{121,122}$ The CDK inhibitor, R-roscovitine, induced eosinophil apoptosis in culture by downregulating Mcl-1. ${ }^{122}$ Thus, more direct pharmacologic manipulation of Bcl-2 proteins to induce eosinophil apoptosis may provide an effective therapy. It is worth noting that actively driving airway eosinophil apoptosis is likely to have two beneficial effects. ${ }^{123}$ Firstly, it may tip the eosinophil from a necrotic form of death to an apoptotic death, and thereby limit the release of its arsenal of histotoxic mediators. Secondly, upon phagocytosis of apoptotic cells, resident macrophages release anti-inflammatory cytokines such as transforming growth factor (TGF)- $\beta$ that may dampen the immune response.

\section{Autoimmune disease}

Dysregulated apoptosis has been implicated in the etiology of various autoimmune diseases including rheumatoid arthritis (RA), Type 1 diabetes, systemic lupus erythmatosus, Sjogren's syndrome, and Crohn's disease. Autoimmunity can 
arise because of too much cell death. For example, autoimmune Type 1 diabetes involves excessive apoptosis of pancreatic $\beta$-cells induced by proinflammatory cytokines such as IL-1 $\beta$, TNF- $\alpha$ and IFN(interferon)- $\gamma$ derived from infiltrating cytotoxic T lymphocytes. ${ }^{124} \mathrm{Bcl}-2$ family members are implicated in several instances, for example, the cytokine-induced $\beta$-cell apoptosis involved the $\mathrm{BH} 3$-only protein Bad and the effector protein Bax, whilst Bcl-2 overexpression prevented this $\beta$-cell death. ${ }^{125,126}$ Interestingly, excessive apoptosis may also contribute to the reduction in $\beta$-cell function and number observed in Type 2 diabetes, because increased $\beta$-cell apoptosis is induced by stresses including fatty acids and high blood glucose levels, and hyperglycemia-induced $\beta$-cell apoptosis relies on the Bcl-2-regulated machinery. ${ }^{127}$ Therefore inhibition of $\beta$-cell apoptosis may be therapeutically valuable in the treatment of both autoimmune and non-autoimmune diabetes.

However, insufficient apoptosis can also contribute to autoimmunity. For example, deficient cell death of autoreactive lymphocytes is implicated in joint inflammation with RA. RA is characterized by expansion of lymphocytes, macrophages, and synovial fibroblasts in the RA joint, leading to local inflammation, proliferation of the synovial membrane, and extensive damage to surrounding soft tissue. Increased expression of Bcl-2, Mcl-1, and Bcl- $x_{L}$ may be the cause of this cell expansion and associated synovial hyperplasia. ${ }^{128-130}$ Therefore topical treatment of an RA joint with apoptosis-inducing agents such as BH3-mimetics has been proposed as a means to initiate apoptosis of resident inflammatory cells and resolve disease. ${ }^{131,132}$

\section{Sepsis}

The septic shock and associated multiorgan failure that can occur during chronic infection has been largely attributed to the proinflammatory cytokine storm following excessive induction of the innate immune response. However, somewhat paradoxically, patients with sepsis exhibit lymphopenia as a result of increased apoptosis of B-cells and $\mathrm{CD}^{+}$T-cells, and apoptosis of antigen-presenting dendritic cells. ${ }^{133,134}$ The net result is an impaired adaptive immune response and failure to resist opportunistic secondary infections. Post mortem examination revealed reduced Bcl-2 expression specifically in patients that died of sepsis. In addition, mice transgenic for Bcl-2 in T- and B-cells are completely protected from sepsis-induced lymphocyte apoptosis, leading to greater survival of the mice. ${ }^{135}$ Therefore, blockade of Bcl-2-regulated apoptosis during sepsis may be an effective alternative to the standard, but often ineffective, anticytokine therapies such as interleukin-1 and TNF $\alpha$ - antagonists. ${ }^{136,137}$

\section{Conclusions}

Bcl-2 family members are critical determinants of cell survival in essentially all cells, both during development and in mature differentiated cells. They are the major regulators of stress-induced apoptosis, and in certain cases also regulate the apoptosis induced by death receptors. The current understanding of each of the Bcl-2 family members, their interactions, and final activation of Bak and Bax to permeabilize mitochondria, is now allowing the development of agents that target different steps in the pathway. Success in this strategy promises the ability to treat a range of pathologies, including the removal of harmful cells such as autoreactive lymphocytes or those with damaged DNA. A prominent example is the successful preclinical and Phase I clinical trials of small-molecule BH3-mimetics in certain cancers.

Our ongoing challenges include obtaining a better understanding of the molecular control of apoptosis and so improve the specificity and efficacy of agents that target Bcl-2 proteins. It also seems feasible to develop small molecules that specifically block apoptosis. Clearly, it is crucial to develop means of targeting specific cells, be they transformed lymphocytes in a lymphoma, persistent granulocytes in an asthmatic airway, or $\beta$-cells in a glucose-bathed pancreas. In some cases, acute administration may effectively initiate or block apoptosis in the target cell with limited effect on other cells. Targeting would also be improved by the development of a simple method of profiling the Bcl-2 proteins in each cell type, including in each cancer.

\section{Acknowledgements}

RK and GD are funded by grants from the National Health and Medical Research Council of Australia and Association for International Cancer Research.

\section{Disclosures}

The authors report no conflict of interest in this work.

\section{References}

1. Tsujimoto Y, Ikegaki N, Croce CM. Characterization of the protein product of $b c l-2$, the gene involved in human follicular lymphoma. Oncogene. 1987;2(1):3-7.

2. Vaux DL, Cory S, Adams JM. Bcl-2 gene promotes haemopoietic cell survival and cooperates with c-myc to immortalize pre-B cells. Nature. 1988;335:440-442.

3. Youle RJ, Strasser A. The BCL-2 protein family: Opposing activities that mediate cell death. Nat Rev Mol Cell Biol. 2008;9(1):47-59. 
4. Villunger A, Michalak EM, Coultas L, et al. p53- and drug-induced apoptotic responses mediated by $\mathrm{BH} 3$-only proteins Puma and Noxa. Science. 2003;302:1036-1038.

5. Puthalakath H, Huang DCS, O'Reilly LA, King SM, Strasser A. The pro-apoptotic activity of the Bcl-2 family member Bim is regulated by interaction with the dynein motor complex. Mol Cell. 1999;3:287-296.

6. Puthalakath H, Villunger A, O'Reilly LA, et al. Bmf: A pro-apoptotic $\mathrm{BH} 3$-only protein regulated by interaction with the myosin $\mathrm{V}$ actin motor complex, activated by anoikis. Science. 2001;293:1829-1832.

7. Scorilas A, Kyriakopoulou L, Yousef GM, Ashworth LK, Kwamie A, Diamandis EP. Molecular cloning, physical mapping, and expression analysis of a novel gene, BCL2L12, encoding a proline-rich protein with a highly conserved $\mathrm{BH} 2$ domain of the Bcl-2 family. Genomics. 2001;72(2):217-221.

8. Coultas L, Pellegrini M, Visvader JE, et al. Bfk: A novel weakly proapoptotic member of the Bcl-2 protein family with a $\mathrm{BH} 3$ and a BH2 region. Cell Death Differ. 2003;10(2):185-192.

9. Guo B, Godzik A, Reed JC. Bcl-G, a novel pro-apoptotic member of the Bcl-2 family. J Biol Chem. 2001;276(4):2780-2785.

10. Stegh AH, Kim H, Bachoo RM, et al. Bcl2L12 inhibits postmitochondrial apoptosis signaling in glioblastoma. Genes Dev. 2007;21(1):98-111.

11. Kataoka T, Holler N, Micheau O, et al. Bcl-rambo, a novel Bcl-2 homologue that induces apoptosis via its unique $\mathrm{C}$-terminal extension. $\mathrm{J} \mathrm{Biol}$ Chem. 2001;276(22):19548-19554.

12. Hockenbery DM, Oltvai ZN, Yin XM, Milliman CL, Korsmeyer S. Bcl-2 functions in an antioxidant pathway to prevent apoptosis. Cell. 1993; 74:241-251.

13. Veis DJ, Sorenson CM, Shutter JR, Korsmeyer SJ. Bcl-2-deficient mice demonstrate fulminant lymphoid apoptosis, polycystic kidneys, and hypopigmented hair. Cell. 1993;75:229-240.

14. Gardner A, Xu FH, Fady C, Sarafian T, Tu Y, Lichtenstein A. Evidence against the hypothesis that BCL-2 inhibits apoptosis through an anti-oxidant effect. Cell Death Differ. 1997;4:487-496.

15. Nakagawa T, Shimizu S, Watanabe T, et al. Cyclophilin D-dependent mitochondrial permeability transition regulates some necrotic but not apoptotic cell death. Nature. 2005;434(7033):652-658.

16. Newmeyer DD, Farschon DM, Reed JC. Cell-free apoptosis in Xenopus egg extracts: Inhibition by Bcl-2 and requirement for an organelle fraction enriched in mitochondria. Cell. 1994;79(2):353-364.

17. Kluck RM, Bossy-Wetzel E, Green DR, Newmeyer DD. The release of cytochrome $c$ from mitochondria - a primary site for Bcl-2 regulation of apoptosis. Science. 1997;275(5303):1132-1136.

18. Yang J, Liu XS, Bhalla K, et al. Prevention of apoptosis by Bcl-2 - release of cytochrome c from mitochondria blocked. Science. 1997;275(5303): 1129-1132.

19. Liu X, Kim CN, Yang J, Jemmerson R, Wang X. Induction of apoptotic program in cell-free extracts: Requirement for dATP and cytochrome c. Cell. 1996;86:147-157.

20. Verhagen AM, Ekert PG, Pakusch M, et al. Identification of DIABLO, a mammalian protein that promotes apoptosis by binding to and antagonizing inhibitor of apoptosis (IAP) proteins. Cell. 2000;102(1):43-53.

21. Du C, Fang M, Li Y, Li L, Wang X. Smac, a mitochondrial protein that promotes cytochrome $c$-dependent caspase activation by eliminating IAP inhibition. Cell. 2000;102(1):33-42.

22. Scaffidi C, Fulda S, Srinivasan A, et al. Two CD95 (APO-1/Fas) signaling pathways. EMBO J. 1998;17(6):1675-1687.

23. McKenzie MD, Carrington EM, Kaufmann T, et al. Proapoptotic $\mathrm{BH} 3$-only protein Bid is essential for death receptor-induced apoptosis of pancreatic beta-cells. Diabetes. 2008;57(5):1284-1292.

24. Yin XM, Wang K, Gross A, et al. Bid-deficient mice are resistant to Fas-induced hepatocellular apoptosis. Nature. 1999;400(6747):886-891.

25. Wolter KG, Hsu YT, Smith CL, Nechushtan A, Xi XG, Youle RJ. Movement of Bax from the cytosol to mitochondria during apoptosis. J Cell Biol. 1997;139(5):1281-1292.
26. Wilson-Annan J, O'Reilly LA, Crawford SA, et al. Proapoptotic $\mathrm{BH} 3-$ only proteins trigger membrane integration of prosurvival $\mathrm{Bcl}-\mathrm{w}$ and neutralize its activity. J Cell Biol. 2003;162(5):877-888.

27. Hsu YT, Wolter KG, Youle RJ. Cytosol-to-membrane redistribution of Bax and Bcl-X during apoptosis. Proc Natl Acad Sci U S A. 1997;94:3668-3672.

28. He H, Lam M, McCormick TS, Distelhorst CW. Maintenance of calcium homeostasis in the endoplasmic reticulum by Bcl-2. J Cell Biol. 1997;138(6):1219-1228.

29. Zong WX, Li C, Hatzuvassiliou G, et al. Bax and Bak can localize to the endoplasmic reticulum to initiate apoptosis. J Cell Biol. 2003;162(1):59-69.

30. Wei MC, Lindsten T, Mootha VK, et al. tBID, a membrane-targeted death ligand, oligomerizes BAK to release cytochrome c. Genes Dev. 2000;14(16):2060-2071.

31. Scorrano L, Oakes SA, Opferman JT, et al. BAX and BAK regulation of endoplasmic reticulum $\mathrm{Ca} 2+$ : A control point for apoptosis. Science. 2003;300(5616):135-139.

32. Nechushtan A, Smith CL, Lamensdorf I, Yoon SH, Youle RJ. Bax and Bak coalesce into novel mitochondria-associated clusters during apoptosis. J Cell Biol. 2001;153(6):1265-1276.

33. Griffiths GJ, Dubrez L, Morgan CP, et al. Cell damage-induced conformational changes of the pro-apoptotic protein Bak in vivo precede the onset of apoptosis. J Cell Biol. 1999;144(5):903-914.

34. Nechushtan A, Smith CL, Hsu YT, Youle RJ. Conformation of the Bax C-terminus regulates subcellular location and cell death. EMBO J. 1999;18(9):2330-2341.

35. Korsmeyer SJ, Wei MC, Saito M, Weiler S, Oh KJ, Schlesinger PH. Pro-apoptotic cascade activates BID, which oligomerizes BAK or BAX into pores that result in the release of cytochrome $c$. Cell Death Differ. 2000;7(12):1166-1173.

36. Chipuk JE, Green DR. How do BCL-2 proteins induce mitochondrial outer membrane permeabilization? Trends Cell Biol. 2008;18(4):157-164.

37. Dewson G, Kluck RM. Mechanisms by which Bak and Bax permeabilise mitochondria during apoptosis. J Cell Sci. 2009;122 (Pt 16):2801-2808.

38. Letai A, Bassik M, Walensky L, Sorcinelli M, Weiler S, Korsmeyer $\mathrm{S}$. Distinct $\mathrm{BH} 3$ domains either sensitize or activate mitochondrial apoptosis, serving as prototype cancer therapeutics. Cancer Cell. 2002;2(3):183-192.

39. Wei MC, Zong WX, Cheng EH, et al. Proapoptotic BAX and BAK: A requisite gateway to mitochondrial dysfunction and death. Science. 2001;292(5517):727-730.

40. Willis SN, Fletcher JI, Kaufmann T, et al. Apoptosis initiated when BH3 ligands engage multiple Bcl-2 homologs, not Bax or Bak. Science. 2007;315(5813):856-859.

41. Willis SN, Chen L, Dewson G, et al. Pro-apoptotic Bak is sequestered by $\mathrm{Mc1}-1$ and Bcl-xL, but not Bcl-2, until displaced by BH3-only proteins. Genes Dev. 2005;19(11):1294-1305.

42. Ruffolo SC, Shore GC. BCL-2 selectively interacts with the BID-induced open conformer of BAK, inhibiting BAK auto-oligomerization. J Biol Chem. 2003;278(27):25039-25045.

43. Leber B, Lin J, Andrews DW. Embedded together: The life and death consequences of interaction of the Bcl-2 family with membranes. Apoptosis. 2007;12(5):897-911.

44. Muchmore SW, Sattler M, Liang H, et al. X-ray and NMR structure of human Bcl-x $\mathrm{x}_{\mathrm{L}}$, an inhibitor of programmed cell death. Nature. 1996;381:335-341.

45. Petros AM, Medek A, Nettesheim DG, et al. Solution structure of the antiapoptotic protein bcl-2. Proc Natl Acad Sci U S A. 2001;98(6): 3012-3017.

46. Day CL, Chen L, Richardson SJ, Harrison PJ, Huang DCS, Hinds MG. Solution structure of prosurvival Mcl-1 and characterization of its binding by proapoptotic BH3-only ligands. J Biol Chem. 2005;280(6):4738-4744.

47. Hinds MG, Lackmann M, Skea GL, Harrison PJ, Huang DCS, Day $\mathrm{CL}$. The structure of Bcl-w reveals a role for the $\mathrm{C}$-terminal residues in modulating biological activity. EMBO J. 2003;22(7):1497-1507. 
48. Smits C, Czabotar PE, Hinds MG, Day CL. Structural plasticity underpins promiscuous binding of the prosurvival protein A1. Structure. 2008;16(5):818-829.

49. Czabotar PE, Lee EF, van Delft MF, et al. Structural insights into the degradation of Mcl-1 induced by BH3 domains. PNAS. 2007;104(15):6217-6222.

50. Sattler M, Liang H, Nettesheim D, et al. Structure of Bcl- $x_{L}-B a k$ peptide complex: Recognition between regulators of apoptosis. Science. 1997;275(5302):983-986.

51. Petros AM, Nettseheim DG, Wang Y, et al. Rationale for Bcl- $x_{L} / B a d$ peptide complex formation from structure, mutagenesis, and biophysical studies. Protein Sci. 2000;9:2528-2534.

52. Suzuki M, Youle RJ, Tjandra N. Structure of Bax: Coregulation of dimer formation and intracellular localization. Cell. 2000;103:645-654.

53. Moldoveanu T, Liu Q, Tocilj A, Watson MH, Shore G, Gehring K. The $\mathrm{x}$-ray structure of a BAK homodimer reveals an inhibitory zinc binding site. Mol Cell. 2006;24(5):677-688.

54. Petros AM, Olejniczak ET, Fesik SW. Structural biology of the Bcl-2 family of proteins. Biochim Biophys Acta. 2004;1644(2-3):83-94.

55. Hinds MG, Smits C, Fredericks-Short R, et al. Bim, Bad and Bmf: Intrinsically unstructured $\mathrm{BH} 3$-only proteins that undergo a localized conformational change upon binding to prosurvival Bcl-2 targets. Cell Death Differ. 2007;14:128-136.

56. Chou JJ, Li H, Salvesen GS, Yuan J, Wagner G. Solution structure of BID, an intracellular amplifier of apoptotic signaling. Cell. 1999;96(5):615-624.

57. McDonnell JM, Fushman D, Milliman CL, Korsmeyer SJ, Cowburn D. Solution structure of the proapoptotic molecule BID: A structural basis for apoptotic agonists and antagonists. Cell. 1999;96(5): 625-634.

58. Yao Y, Bobkov AA, Plesniak LA, Marassi FM. Mapping the interaction of pro-apoptotic tBID with pro-survival BCL-XL. Biochemistry. 2009;48(36):8704-8711.

59. Chen L, Willis SN, Wei A, et al. Differential targeting of pro-survival Bcl-2 proteins by their BH3-only ligands allows complementary apoptotic function. Mol Cell. 2005;17:393-403.

60. Dewson G, Kratina T, Sim HW, et al. To trigger apoptosis Bak exposes its $\mathrm{BH} 3$ domain and homo-dimerizes via $\mathrm{BH} 3$ : Groove interactions. Mol Cell. 2008;30(3):369-380.

61. Bleicken S, Classen M, Padmavathi PV, et al. Molecular details of Bax activation, oligomerization and membrane insertion. J Biol Chem. 2010;285(9):6636-6647.

62. Gavathiotis E, Suzuki M, Davis ML, et al. BAX activation is initiated at a novel interaction site. Nature. 2008;455(7216):1076-1081.

63. Kim H, Tu HC, Ren D, et al. Stepwise activation of BAX and BAK by tBID, BIM, and PUMA initiates mitochondrial apoptosis. Mol Cell. 2009;36(3):487-499.

64. Griffiths GJ, Corfe BM, Savory P, et al. Cellular damage signals promote sequential changes at the N-terminus and $\mathrm{BH}-1$ domain of the pro-apoptotic protein Bak. Oncogene. 2001;20(52):7668-7676.

65. Annis MG, Soucie EL, Dlugosz PJ, et al. Bax forms multispanning monomers that oligomerize to permeabilize membranes during apoptosis. EMBO J. 2005;24(12):2096-2103.

66. Kim PK, Annis MG, Dlugosz PJ, Leber B, Andrews DW. During apoptosis bcl-2 changes membrane topology at both the endoplasmic reticulum and mitochondria. Mol Cell. 2004;14:523-529.

67. Antignani A, Youle RJ. How do Bax and Bak lead to permeabilization of the outer mitochondrial membrane? Curr Opin Cell Biol. 2006;18(6):685-689.

68. Dlugosz PJ, Billen LP, Annis MG, et al. Bcl-2 changes conformation to inhibit Bax oligomerization. EMBO J. 2006;25(11):2287-2296.

69. Gong XM, Choi J, Franzin CM, Zhai D, Reed JC, Marassi FM. Conformation of membrane-associated proapoptotic tBid.J Biol Chem. 2004;279(28):28954-28960.

70. Aisenbrey C, Sudheendra US, Ridley H, et al. Helix orientations in membrane-associated Bcl-X(L) determined by $15 \mathrm{~N}$-solid-state NMR spectroscopy. Eur Biophys J. 2007;37(1):71-80.
71. Losonczi JA, Olejniczak ET, Betz SF, Harlan JE, Mack J, Fesik SW. NMR studies of the anti-apoptotic protein Bcl-xL in micelles. Biochemistry. 2000;39(36):11024-11033.

72. Franzin CM, Choi J, Zhai D, Reed JC, Marassi FM. Structural studies of apoptosis and ion transport regulatory proteins in membranes. Magn Reson Chem. 2004;42(2):172-179.

73. Kvansakul M, Yang H, Fairlie WD, et al. Vaccinia virus anti-apoptotic F1L is a novel Bcl-2-like domain-swapped dimer that binds a highly selective subset of BH3-containing death ligands. Cell Death Differ. 2008;15(10):1564-1571.

74. Douglas AE, Corbett KD, Berger JM, McFadden G, Handel TM. Structure of M11L: A myxoma virus structural homolog of the apoptosis inhibitor, Bcl-2. Protein Sci. 2007;16(4):695-703.

75. Huang Q, Petros AM, Virgin HW, Fesik SW, Olejniczak ET. Solution structure of the BHRF1 protein from Epstein-Barr virus, a homolog of human Bcl-2. J Mol Biol. 2003;332(5):1123-1130.

76. Postigo A, Cross JR, Downward J, Way M. Interaction of F1L with the $\mathrm{BH} 3$ domain of Bak is responsible for inhibiting vaccinia-induced apoptosis. Cell Death Differ. 2006;13(10):1651-1662.

77. Wang G, Barrett JW, Nazarian SH, et al. Myxoma virus M11L prevents apoptosis through constitutive interaction with Bak. J Virol. 2004;78(13):7097-111.

78. Graham SC, Bahar MW, Cooray S, et al. Vaccinia virus proteins A52 and B14 share a Bcl-2-like fold but have evolved to inhibit NF-kappaB rather than apoptosis. PLoS Pathog. 2008;4(8):e1000128.

79. Motoyama N, Wang FP, Roth KA, et al. Massive cell death of immature hematopoietic cells and neurons in Bcl-x deficient mice. Science. 1995;267:1506-1510

80. Opferman JT, Letai A, Beard C, Sorcinelli MD, Ong CC, Korsmeyer SJ. Development and maintenance of $\mathrm{B}$ and $\mathrm{T}$ lymphocytes requires antiapoptotic MCL-1. Nature. 2003;426(6967):671-676.

81. Hakem R, Hakem A, Duncan GS, et al. Differential requirement for caspase 9 in apoptotic pathways in vivo. Cell. 1998;94(3):339-352.

82. Kuida K, Haydar TF, Kuan CY, et al. Reduced apoptosis and cytochrome c-mediated caspase activation in mice lacking caspase 9. Cell. 1998;94(3):325-337.

83. Yoshida H, Kong YY, Yoshida R, et al. Apaf1 is required for mitochondrial pathways of apoptosis and brain development. Cell. 1998;94(6): 739-750.

84. Hao Z, Duncan GS, Chang CC, et al. Specific ablation of the apoptotic functions of cytochrome $\mathrm{C}$ reveals a differential requirement for cytochrome C and Apaf-1 in apoptosis. Cell. 2005;121(4): 579-591.

85. Lindsten T, Ross AJ, King A, et al. The combined functions of proapoptotic Bcl-2 family members Bak and Bax are essential for normal development of multiple tissues. Mol Cell. 2000;6(6):1389-1399.

86. Knudson CM, Tung KSK, Tourtellotte WG, Brown GAJ, Korsmeyer SJ. Bax-deficient mice with lymphoid hyperplasia and male germ cell death. Science. 1995;270:96-99.

87. Bouillet P, Metcalf D, Huang DCS, et al. Proapoptotic Bcl-2 relative Bim required for certain apoptotic responses, leukocyte homeostasis, and to preclude autoimmunity. Science. 1999;286:1735-1738.

88. Kerr JFR, Wyllie AH, Currie AR. Apoptosis: A basic biological phenomenon with wide-ranging implications in tissue kinetics. Br J Cancer. 1972;26:239-257.

89. Hanahan D, Weinberg RA. The hallmarks of cancer. Cell. 2000;100(1): 57-70.

90. Strasser A, Harris AW, Bath ML, Cory S. Novel primitive lymphoid tumours induced in transgenic mice by cooperation between myc and bcl-2. Nature. 1990;348:331-333.

91. Pepper C, Hoy T, Bentley DP. Bcl-2/Bax ratios in chronic lymphocytic leukaemia and their correlation with in vitro apoptosis and clinical resistance. Br J Cancer. 1997;76(7):935-938.

92. Ouyang H, Furukawa T, Abe T, Kato Y, Horii A. The BAX gene, the promoter of apoptosis, is mutated in genetically unstable cancers of the colorectum, stomach, and endometrium. Clin Cancer Res. 1998;4(4):1071-1074. 
93. Jansson A, Sun XF. Bax expression decreases significantly from primary tumor to metastasis in colorectal cancer. J Clin Oncol. 2002;20(3): 811-816.

94. Fecker LF, Geilen CC, Tchernev G, et al. Loss of proapoptotic Bcl2-related multidomain proteins in primary melanomas is associated with poor prognosis. J Invest Dermatol. 2006;126(6):1366-1371.

95. Kang MH, Reynolds CP. Bcl-2 inhibitors: Targeting mitochondrial apoptotic pathways in cancer therapy. Clin Cancer Res. 2009;15(4): 1126-1132.

96. Oltersdorf T, Elmore SW, Shoemaker AR, et al. An inhibitor of Bcl-2 family proteins induces regression of solid tumours. Nature. 2005;435(7042):677-681.

97. Lee EF, Czabotar PE, Smith BJ, et al. Crystal structure of ABT-737 complexed with $\mathrm{Bcl}-\mathrm{x}(\mathrm{L})$ : Implications for selectivity of antagonists of the Bcl-2 family. Cell Death Differ. 2007;14(9):1711-1713.

98. Certo M, del Gaizo Moore G, Nishino M, et al. Mitochondria primed by death signals determine cellular addiction to antiapoptotic BCL-2 family members. Cancer Cell. 2006;9(5):351-365.

99. Chauhan D, Velankar M, Brahmandam M, et al. A novel Bcl-2/Bcl$\mathrm{X}(\mathrm{L}) / \mathrm{Bcl}-\mathrm{w}$ inhibitor ABT-737 as therapy in multiple myeloma. Oncogene. 2007;26(16):2374-2380.

100. Kang MH, Kang YH, Szymanska B, et al. Activity of vincristine, L-ASP, and dexamethasone against acute lymphoblastic leukemia is enhanced by the BH3-mimetic ABT-737 in vitro and in vivo. Blood 2007;110(6):2057-2066.

101. Del Gaizo Moore V, Brown JR, Certo M, Love TM, Novina CD, Letai A. Chronic lymphocytic leukemia requires BCL2 to sequester prodeath BIM, explaining sensitivity to BCL2 antagonist ABT-737. J Clin Invest. 2007;117(1):112-121.

102. Tse C, Shoemaker AR, Adickes J, et al. ABT-263: A potent and orally bioavailable Bcl-2 family inhibitor. Cancer Res. 2008;68(9): 3421-3428.

103. Michaelidis TM, Sendtner M, Cooper JD, et al. Inactivation of $b c l-2$ results in progressive degeneration of motoneurons, sympathetic and sensory neurons during early postnatal development. Neuron. 1996; 17:75-89.

104. Martinou JC, Dubois-Dauphin M, Staple JK, et al. Overexpression of Bcl-2 in transgenic mice protects neurons from naturally occurring cell death and experimental ischemia. Neuron. 1994;13:1017-1030.

105. Perier C, Bove J, Wu DC, et al. Two molecular pathways initiate mitochondria-dependent dopaminergic neurodegeneration in experimental Parkinson's disease. Proc Natl Acad Sci U S A. 2007; 104(19):8161-8166.

106. Armstrong JS. Mitochondrial medicine: Pharmacological targeting of mitochondria in disease. Br J Pharmacol. 2007;151(8):1154-1165.

107. Youdim MB, Amit T, Bar-Am O, Weinreb O, Yogev-Falach M. Implications of co-morbidity for etiology and treatment of neurodegenerative diseases with multifunctional neuroprotective-neurorescue drugs; ladostigil. Neurotox Res. 2006;10(3-4):181-192.

108. Gustafsson AB, Gottlieb RA. Bcl-2 family members and apoptosis, taken to heart. Am J Physiol Cell Physiol. 2007;292(1):C45-C51.

109. Kirshenbaum LA, de Moissac D. The bcl-2 gene product prevents programmed cell death of ventricular myocytes. Circulation. 1997;96(5):1580-1585.

110. Imahashi K, Schneider MD, Steenbergen C, Murphy E. Transgenic expression of Bcl-2 modulates energy metabolism, prevents cytosolic acidification during ischemia, and reduces ischemia/reperfusion injury. Circ Res. 2004;95(7):734-741.

111. Maulik N, Engelman RM, Rousou JA, Flack JE, 3rd, Deaton D, Das DK. Ischemic preconditioning reduces apoptosis by upregulating anti-death gene Bcl-2. Circulation. 1999;100(19 Supp1): II369-II375.

112. Hochhauser E, Cheporko Y, Yasovich N, et al. Bax deficiency reduces infarct size and improves long-term function after myocardial infarction. Cell Biochem Biophys. 2007;47(1):11-20.

113. Webster KA. Programmed death as a therapeutic target to reduce myocardial infarction. Trends Pharmacol Sci. 2007;28(9):492-499.
114. Dewson G, Wardlaw AM, Walsh GM. Human eosinophils: Apoptosis versus survival in the mediation of inflammation. Apoptosis. 1996;1:111-118.

115. Kankaanranta H, Lindsay MA, Giembycz MA, Zhang X, Moilanen E, Barnes PJ. Delayed eosinophil apoptosis in asthma. J Allergy Clin Immunol. 2000;106(1):77-83.

116. Tumes DJ, Wong AC, Sewell WA, McColl SR, Connolly A, Dent LA. Differential rates of apoptosis and recruitment limit eosinophil accumulation in the lungs of asthma-resistant CBA/Ca mice. $\mathrm{Mol}$ Immunol. 2008;45(13):3609-3617.

117. Dewson G, Walsh GM, Wardlaw AJ. Expression of Bcl-2 and its homologues in human eosinophils. Modulation by interleukin-5. Am J Respir Cell Mol Biol. 1999;20(4):720-728.

118. Dewson G, Cohen GM, Wardlaw AJ. Interleukin-5 inhibits translocation of Bax to the mitochondria, cytochrome $\mathrm{c}$ release, and activation of caspases in human eosinophils. Blood. 2001;98(7): 2239-2247.

119. Jang AS, Choi IS, Lee S, Seo JP, Yang SW, Park CS. Bcl-2 expression in sputum eosinophils in patients with acute asthma. Thorax. 2000;55(5):370-374.

120. El-Gamal Y, Heshmat N, Mahran M, El-Gabbas Z. Expression of the apoptosis inhibitor Bcl-2 in sputum eosinophils from children with acute asthma. Clin Exp Allergy. 2004;34(11):1701-1706.

121. Steinke JW, Borish L. Th2 cytokines and asthma. Interleukin-4: Its role in the pathogenesis of asthma, and targeting it for asthma treatment with interleukin-4 receptor antagonists. Respir Res. 2001;2(2): 66-70.

122. Duffin R, Leitch AE, Sheldrake TA, et al. The CDK inhibitor, R-roscovitine, promotes eosinophil apoptosis by down-regulation of Mcl-1. FEBS Lett. 2009;583(15):2540-2546.

123. Fadok VA, Bratton DL, Konowal A, Freed PW, Westcott JY, Henson PM. Macrophages that have ingested apoptotic cells in vitro inhibit proinflammatory cytokine production through autocrine/paracrine mechanisms involving TGF-beta, PGE2, and PAF. J Clin Invest 1998;101(4):890-898.

124. Butler AE, Janson J, Bonner-Weir S, Ritzel R, Rizza RA, Butler PC. Beta-cell deficit and increased beta-cell apoptosis in humans with type 2 diabetes. Diabetes. 2003;52(1):102-110.

125. Grunnet LG, Aikin R, Tonnesen MF, et al. Proinflammatory cytokines activate the intrinsic apoptotic pathway in beta-cells. Diabetes. 2009;58(8):1807-1815.

126. Tran VV, Chen G, Newgard CB, Hohmeier HE. Discrete and complementary mechanisms of protection of beta-cells against cytokine-induced and oxidative damage achieved by bcl-2 overexpression and a cytokine selection strategy. Diabetes. 2003;52(6): 1423-1432.

127. McKenzie MD, Jamieson E, Jansen ES, et al. Glucose induces pancreatic islet cell apoptosis that requires the $\mathrm{BH} 3$-only proteins $\mathrm{Bim}$ and Puma and multi-BH domain protein Bax. Diabetes. 2010;59(3) 644-652.

128. Perlman H, Georganas C, Pagliari LJ, Koch AE, Haines K 3rd, Pope RM. Bcl-2 expression in synovial fibroblasts is essential for maintaining mitochondrial homeostasis and cell viability. J Immunol. 2000;164(10):5227-5235.

129. Busteed S, Bennett MW, Molloy C, et al. Bcl-x(L) expression in vivo in rheumatoid synovium. Clin Rheumatol. 2006;25(6):789-793.

130. Liu H, Eksarko P, Temkin V, et al. Mcl-1 is essential for the survival of synovial fibroblasts in rheumatoid arthritis. J Immunol. 2005;175(12):8337-8345.

131. Liu H, Pope RM. The role of apoptosis in rheumatoid arthritis. Curr Opin Pharmacol. 2003;3(3):317-322.

132. Hutcheson J, Perlman H. BH3-only proteins in rheumatoid arthritis: Potential targets for therapeutic intervention. Oncogene. 2008;27 Suppl 1:S168-S175.

133. Hotchkiss RS, Tinsley KW, Swanson PE, et al. Sepsis-induced apoptosis causes progressive profound depletion of B and CD4 ${ }^{+} \mathrm{T}$ lymphocytes in humans. J Immunol. 2001;166(11):6952-6963. 
134. Tinsley KW, Grayson MH, Swanson PE, et al. Sepsis induces apoptosis and profound depletion of splenic interdigitating and follicular dendritic cells. J Immunol. 2003;171(2):909-914.

135. Hotchkiss RS, Swanson PE, Knudson CM, et al. Overexpression of Bcl-2 in transgenic mice decreases apoptosis and improves survival in sepsis. J Immunol. 1999;162:4148-4156.

136. Hotchkiss RS, Nicholson DW. Apoptosis and caspases regulate death and inflammation in sepsis. Nat Rev Immunol. 2006;6(11):813-822.
137. Wesche-Soldato DE, Swan RZ, Chung CS, Ayala A. The apoptotic pathway as a therapeutic target in sepsis. Curr Drug Targets. 2007;8(4):493-500.

138. Huang DCS, Adams JM, Cory S. The conserved N-terminal BH4 domain of Bcl-2 homologues is essential for inhibition of apoptosis and interaction with CED-4. EMBO J. 1998;17(4):1029-1039.

\section{Publish your work in this journal}

Cell Health and Cytoskeleton is an international, peer-reviewed open access journal focusing on all aspects of cell structure and function contributing to normal physiology and cell health and exploring the pathogenesis of cell dysfunction leading to adverse conditions and disease in the organism. The journal welcomes papers covering original research,

\section{Dovepress}

basic science, reviews and evaluations, guidelines, expert opinion and commentary, case reports and extended reports. The manuscript management system is completely online and includes a very quick and fair peerreview system, which is all easy to use. Visit http://www.dovepress.com/ testimonials.php to read real quotes from published authors. 